\title{
Novel Hybrid Fuzzy-PID Control Scheme for Air Supply in PEM Fuel-Cell-based Systems
}

\author{
Zakaria BAROUD ${ }^{\mathrm{a}, \mathrm{b}, *}$, Mohammed BENMILOUD ${ }^{\mathrm{a}}$, Atallah BENALIA ${ }^{\mathrm{a}}$, \\ Carlos OCAMPO-MARTINEZ ${ }^{\mathrm{b}}$ \\ ${ }^{a}$ Laboratoire d'Analyse et de Commande des Systmes d'Énergies et Réseaux Électriques. \\ Université Amar Telidji de Laghouat, Laghouat 03000, Algérie \\ ${ }^{b}$ Automatic Control Department, Universitat Politècnica de Catalunya, Institut de Robòtica \\ i Informàtica Industrial (CSIC-UPC), C/ Llorens i Artigas 4-6, 08028 Barcelona, Spain
}

\begin{abstract}
This paper proposes a novel hybrid fuzzy-PID controller for air supply on Proton Exchange Membrane fuel cell (PEMFC) systems. The control objective is to adjust the oxygen excess ratio at a given setpoint in order to prevent oxygen starvation and damage of the fuel-cell stack. The proposed control scheme consists of three parts: a fuzzy-logic controller (FLC), a fuzzy-based self-tuned PID (FSTPID) controller and a fuzzy selector. Depending on the value of the error between the current value of oxygen excess ratio and its setpoint value, the fuzzy selector decides which controller should play the greatest effect on the control system. The performance of the proposed control strategy is analysed through simulations for different load variations and for parameter uncertainties. The results show that the novel hybrid fuzzy-PID controller performs significantly better than the classical PID controller and the FLC in terms of several key performance indices such as the Integral Squared Error (ISE), the Integral Absolute Error (IAE) and the Integral Time-weighted Absolute Error (ITAE), as well as the overshoot, settling and rise time for the closed-loop control system.
\end{abstract}

Keywords: Proton Exchange Membrane Fuel Cell, Oxygen excess ratio, Oxygen starvation, Fuzzy logic controller, Fuzzy selector, Hybrid fuzzy-PID controller.

\section{Introduction}

The serious environmental pollution and energy crisis around the world are driving innovation on new efficient and clean energy sources such as solar, wind,

\footnotetext{
* Corresponding author.

Email addresses: z.baroud@lagh-univ.dz (Zakaria BAROUD), med.benmiloud@lagh-univ.dz (Mohammed BENMILOUD), a.benalia@lagh-univ.dz (Atallah BENALIA), cocampo@iri.upc.edu (Carlos OCAMPO-MARTINEZ)
} 
geothermal and hydrogen. Fuel cells are a kind of clean energy, which produce electricity, water and heat from hydrogen and oxygen [1, 2, 3.

In particular, Proton Exchange Membrane fuel cells (PEMFC), also called solid polymer fuel cells (SPFCs), are considered to be more developed than other types of fuel cells 4, 5, 6. They are used in a wide range of applications, with advantages such as high efficiency, low weight, low pollution and low operation temperature, features that allow fast starting times in the PEMFC systems [7, 8. However, high expenses and short lifetime have hindered their massive utilization in real systems so far. As a result, advanced control systems are required to improve the lifetime and avoid the detrimental degradation of the PEMFC system.

Many control strategies have been proposed for PEMFC systems in the literature. It can be cited, among others, linear control methods based on model linearization such as Linear Quadratic Regulator (LQR), proportional integral (PI) plus static feed-forward controller are proposed in [9] and [10]. Kunusch et al. 11] were the first to use second order sliding mode strategy for the air supply PEMFC system, see [12, 13. In [14, 15, 16, different topologies of fuzzy-logic control (FLC) are proposed such as adaptive PID-based FLC, optimal PID plus fuzzy controller and feed-forward fuzzy PID. Other control strategies, as gain scheduled Linear Parameter-Varying (LPV) control [17, fault tolerant unfalsified control [18, Model Predictive Control (MPC) 19, 20, and optimal control [21, 22] were also reported to control the air supply PEMFC-based systems. All these control strategies are applied for the regulation of the oxygen excess ratio in the PEMFC with different degrees of success.

However, these controllers impose certain limitations over the tracking performance and none of them consider uncertainties of system parameters. These drawbacks are addressed in this paper. Here, a novel combining method based on conventional PID and fuzzy-logic controllers is proposed. This proposal bears two major advantages: the strengths of both PID and fuzzy-logic controllers are benefited while the hybrid controller suitably performs with uncertainties of nominal parameters of the PEMFC-based system.

Fuzzy logic was firstly proposed by Lotfi A. Zadeh in 1965 to control plants that were difficult to model [23]. The application of fuzzy logic in control problems was firstly introduced by Mamdani in 1974 [24]. In the present paper, a novel hybrid fuzzy-PID controller is developed to regulate efficiently the oxygen excess ratio at a setpoint value despite the stack current variations in order to avoid oxygen starvation and maximize the net power output. The proposed control scheme is separated into three parts: a fuzzy logic controller, a fuzzybased self-tuned PID controller and a fuzzy selector. The fuzzy selector, based on fuzzy rules, and depending on the error between the current value of oxygen excess ratio and its setpoint value, is used to determine signals that have the greatest effect over the control system. To validate the proposed controller, a reduced version of the ninth-order state-space model is proposed in [25].

The remainder of the paper is organized as follows. Both the mathematical model of the PEMFC air supply system and the control objective are explained in Section 2. In Section 3, modules such as the PID controller, the 
fuzzy controller, the fuzzy self-tuner PID controller and the hybrid fuzzy-PID controller are designed, respectively. The designed control strategies are applied to the model of the PEMFC system and the simulation results for stack current changes, model uncertainties and comparison study are presented in detail in Section 4. Finally, the main conclusions are drawn in Section 5.

\section{PEMFC System Model}

\subsection{Nonlinear Model}

The PEMFC system includes five main subprocesses: the air flow (breathing), the hydrogen flow, the humidifier, the stack electrochemistry and the stack temperature. According to [25], it is considered that sufficient compressed hydrogen is available. In addition, it is assumed that both temperature and humidity of input reactant flows are properly regulated by dedicated local controllers, and thus the main regard is focused on the air management. Under these assumptions, a fourth-order state-space model is derived, which is a reduced version of the ninth-order model presented in [26]. The model equations and constants are summarized in Appendix A. The reader may refer to [26, 27. for further details about the mathematical expressions.

The nonlinear state-space equations in (A.1) can be written in the form

$$
\dot{x}(t)=f(x(t), u(t), w(t)),
$$

where the vector of states $x \in \mathbb{R}^{4}$ is associated to the partial pressure of oxygen and nitrogen in the cathode channel, the rotational speed of the motor shaft in the compressor and the air pressure in the supply manifold, respectively. The control input $u \in \mathbb{R}$, as shown in Figure 1 is the compressor motor voltage $v_{c m}$, which allows the manipulation of the air feed and, as a consequence, the oxygen supply to the fuel-cell stack. The measurable disturbance input $w \in \mathbb{R}$ is the stack current $I_{s t}$. The system outputs $h_{y} \in \mathbb{R}^{3}$, as also shown in Figure 1 , is the stack voltage $h_{y_{1}}=v_{s t}$, the supply manifold pressure $h_{y_{2}}=x_{4}$ and the air flow rate through the compressor $h_{y_{3}}=W_{c p}$, respectively. The latter depends on the rotational speed of the motor shaft in the compressor and the air pressure in the supply manifold, that has been approximated with the following expression:

$$
h_{y_{3}}(t)=\frac{h_{y_{3}}^{\max } x_{3}(t)}{x_{3}^{\max }}\left(1-e^{\left(\frac{-r\left(s+\frac{x_{3}^{2}(t)}{q}-x_{4}(t)\right)}{s+\frac{x_{3}^{2}(t)}{q}-x_{4}^{\min }}\right)}\right),
$$

with $r=15, q=462.25 \mathrm{rad}^{2} /\left(\mathrm{s}^{2} \mathrm{~Pa}\right), x_{3}^{\max }=11500 \mathrm{rad} / \mathrm{s}, x_{4}^{\min }=50000 \mathrm{~Pa}$, $s=10^{5} \mathrm{~Pa}$ and $h_{y_{3}}^{\max }=0.0975 \mathrm{Kg} / \mathrm{s}$. For further details on the functions $h_{y_{1}}$ and $h_{y_{3}}$, see [26, 27]. The performance variables $z \in \mathbb{R}^{2}$, with $z_{1}$ as net power and $z_{2}$ as oxygen excess ratio, follow the expressions in A.2 within Appendix A 


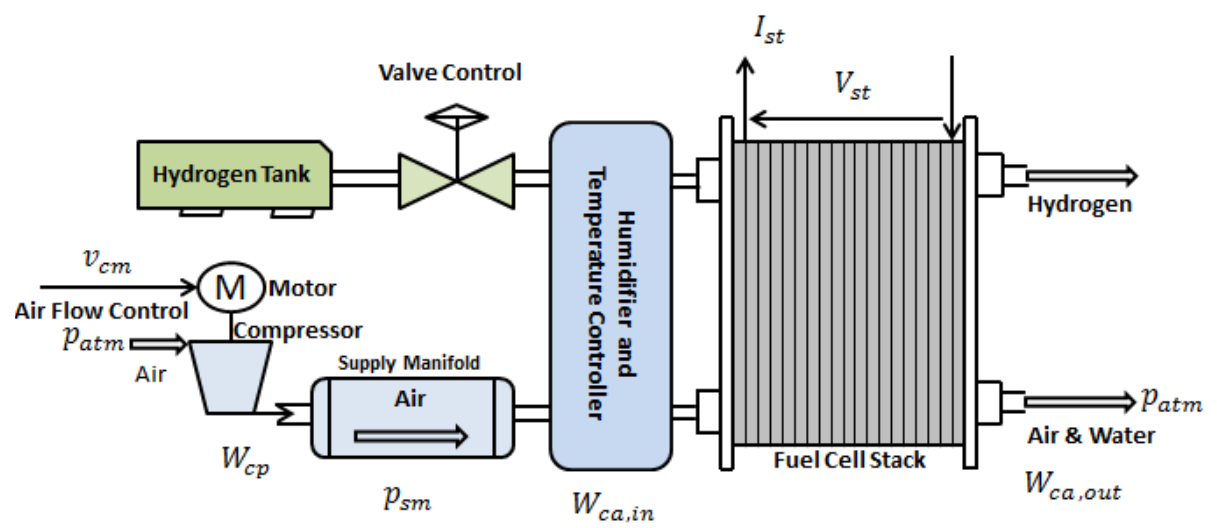

Figure 1: Fuel Cell System showing control inputs and outputs

\subsection{Control objective}

The main control objective for the PEMFC system is to regulate the oxygen excess ratio $z_{2}$, which is defined by the amount of oxygen provided, denoted by $W_{O_{2}, \text { in }}$, and the amount of oxygen reacted, denoted as $W_{O_{2}, r c t}$, through the following expression:

$$
z_{2}(t)=\frac{W_{O_{2}, i n}(t)}{W_{O_{2}, r c t}(t)} .
$$

If the value of $z_{2}$ is quite low, even though higher than 1 , it is likely to cause Oxygen starvation. This phenomenon can cause a short circuit and a hot spot on the surface of the fuel-cell membrane. On the other hand, higher values of $z_{2}$ will drive the compressor motor to consume more power and, therefore, towards lower efficiency operating conditions. As a result, it is necessary to state the optimal value of $z_{2}$ that maximizes the net power $z_{1}$. The relation between the oxygen excess ratio and the net power for different stack currents is called the performance curve (see Figure 2). It can be observed from Figure 2 that the maximum net power $z_{1}$ is achieved at an oxygen excess ratio $z_{2}$ between 1.9 and 2.5 for stack current variations between 100-300 A. However, in order to get the best compromise between safety and efficiency, it is necessary to regulate $z_{2}$ around an optimal value $z_{2, \text { opt }}=2.05$ as discussed in [11. 


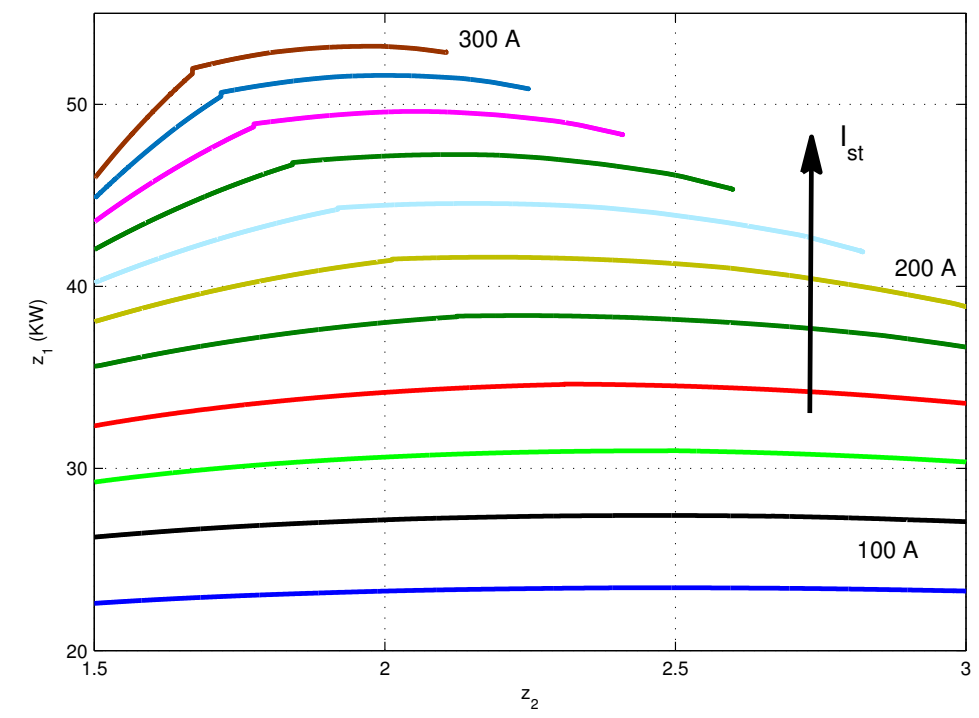

Figure 2: The $z_{2}$ performance curve for different stack currents

\section{Controller Design}

To meet the above control requirements, an efficient control is required to keep the oxygen excess ratio at its optimum value. In this section, several control topologies are introduced and discussed. They are based on

- PID controller,

- Fuzzy logic controller,

- Fuzzy-based self-tuned PID controller.

\subsection{PID Controller}

The PID control scheme, shown in Figure 3, is widely used in industrial process control due to its simple structure and to its robust performance for both linear and nonlinear systems. The mathematical expression of this controller is given by

$$
u_{P I D}(t)=k_{p} e(t)+k_{i} \int e(t) d t+k_{d} \frac{d e(t)}{d t},
$$

where $e$ is the feedback error, that is defined in the case of this paper as the difference between the current value of $z_{2}$ and its setpoint value, i.e.,

$$
e(t)=z_{2}(t)-z_{2, o p t},
$$

and the parameters $k_{p}, k_{i}$ and $k_{d}$ are known as proportional gain, integral gain and derivative gain, respectively. 


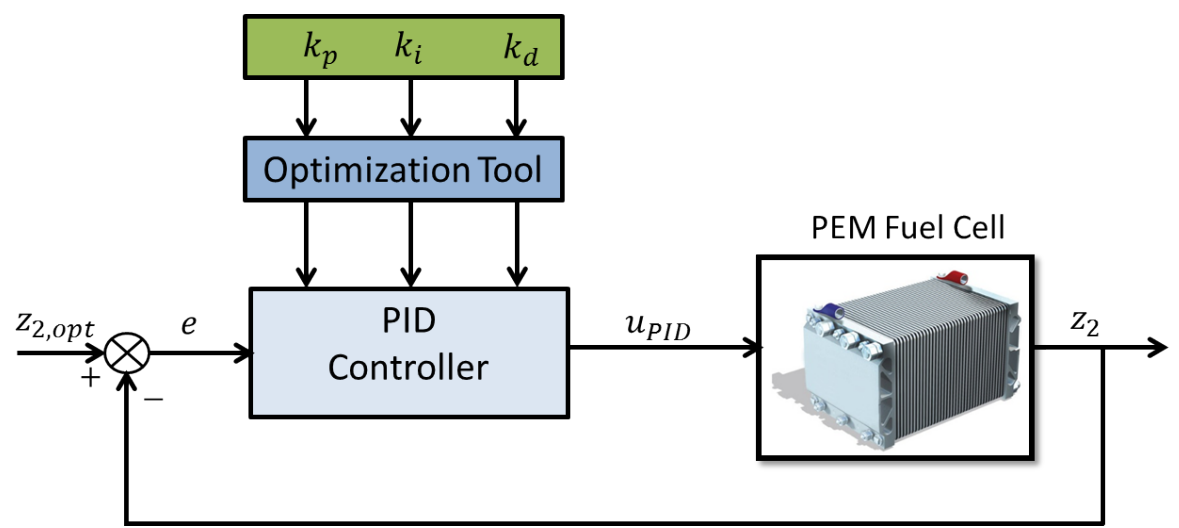

Figure 3: Structure of PID controller

The three PID gains design, $k_{p}, k_{i}$ and $k_{d}$, is not easy task due to the complexity of the PEMFC system model. Therefore, to obtain the corresponding PID parameters an optimization tool in Matlab is needed [28. This command is called fminsearch, which finds the minimum of the quadratic cost function specified by

$$
\int_{0}^{T_{f}}\left(z_{2}(t)-z_{2, o p t}\right)^{2} .
$$

\subsection{Fuzzy Logic Controller}

Fuzzy logic is one of the most versatile control techniques due to its simplicity, efficiency and robustness against the system dynamics variation. The fuzzy logic controller synthesize does not require the precise information of system. It has been successfully used in the PEMFC systems with better performance with respect to the PID controller counterpart [29, 30]. There are three main parts in the fuzzy logic controller (FLC) as shown in Figure 4

- Fuzzification interface converts a crisp input to a fuzzy value by using fuzzy sets,

- Rule base and inference system generates a result for each suitable rule, then combines the results of the rules,

- Defuzzification interface converts the combined result back into a specific control output value.

For the fuzzification and defuzzification interfaces, this controller considers five membership functions, which are justified by the required precision of the closedloop system. 


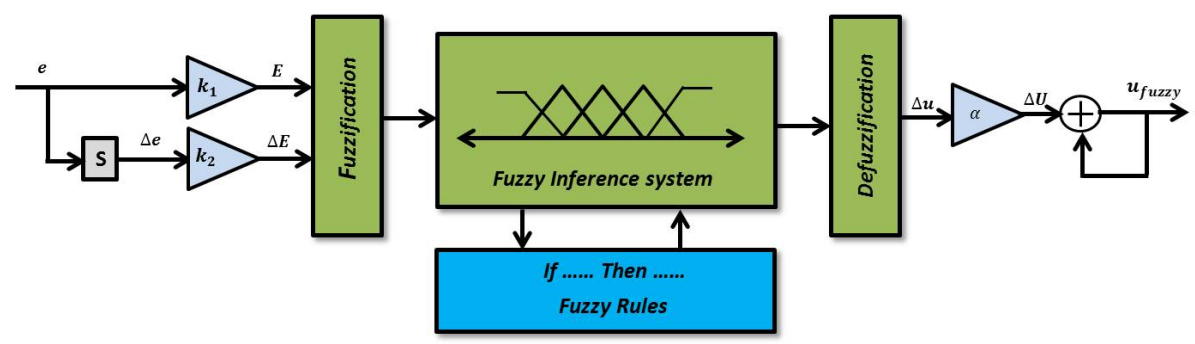

Figure 4: Structure of fuzzy controller

In Figure 4, variables $e, \Delta e, E$ and $\Delta E$ indicate error, derivative of error, normalized error and normalized derivative of error, respectively, while the parameters $k_{1}, k_{2}$ and $\alpha$ are input and output scaling factors, which have an important effect on the system dynamic behaviour. The scaling factors $k_{1}, k_{2}$ and $\alpha$ may be selected, based on control experience and a lot of simulations, among other advanced meta-heuristics approaches [31. In Table 1, the fuzzy linguistic variables are $\mathrm{NB}, \mathrm{N}, \mathrm{Z}, \mathrm{P}$ and $\mathrm{PB}$, which represent negative big, negative, zero, positive and positive big, respectively. The basic form of the fuzzy control rules is: "if the error $E$ is $\mathrm{A}$ and the error derivation $\Delta E$ is $\mathrm{B}$, then the fuzzy control output is $\Delta u$ ".

Table 1: Linear rule base for FLC

\begin{tabular}{|c|l|l|l|l|l|l|}
\hline \multicolumn{2}{|c|}{$\Delta u$} & \multicolumn{5}{|c|}{$E$} \\
\cline { 3 - 7 } \multicolumn{2}{|c|}{} & NB & $\mathbf{N}$ & $\mathbf{Z}$ & $\mathbf{P}$ & $\mathbf{P B}$ \\
\hline \multirow{5}{*}{$\Delta E$} & $\mathbf{N B}$ & $\mathrm{NB}$ & $\mathrm{NB}$ & $\mathrm{N}$ & $\mathrm{N}$ & $\mathrm{Z}$ \\
\cline { 2 - 7 } & $\mathbf{N}$ & $\mathrm{NB}$ & $\mathrm{N}$ & $\mathrm{N}$ & $\mathrm{Z}$ & $\mathrm{P}$ \\
\cline { 2 - 7 } & $\mathbf{Z}$ & $\mathrm{N}$ & $\mathrm{N}$ & $\mathrm{Z}$ & $\mathrm{P}$ & $\mathrm{P}$ \\
\cline { 2 - 7 } & $\mathbf{P}$ & $\mathrm{N}$ & $\mathrm{Z}$ & $\mathrm{P}$ & $\mathrm{P}$ & $\mathrm{PB}$ \\
\cline { 2 - 7 } & $\mathrm{PB}$ & $\mathrm{Z}$ & $\mathrm{P}$ & $\mathrm{P}$ & $\mathrm{PB}$ & $\mathrm{PB}$ \\
\hline
\end{tabular}

The membership functions of the FLC inputs and output are respectively shown in Figures 5(a) and 5(b). 


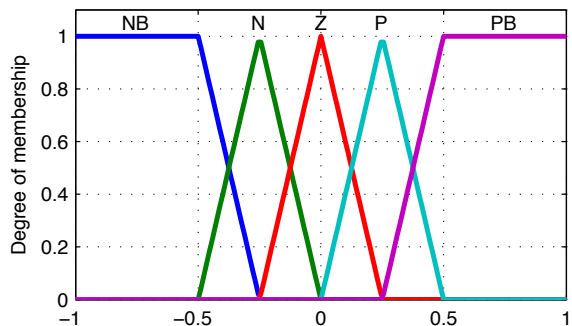

(a) $E$ and $\Delta E$

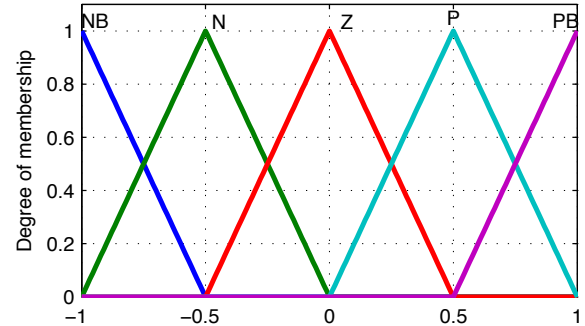

(b) $\Delta u$

Figure 5: Membership functions

\subsection{Fuzzy-based Self-Tuned PID Controller}

The coefficients of the classical PID controller are not always tuned for the nonlinear plant with unpredictable parameter variations. Hence, it is necessary to automatically tune the PID parameters. The fuzzy-based self-tuned PID (FSTPID) controller is designed such that the three-term control $k_{p}, k_{i}$ and $k_{d}$ are tuned by using a fuzzy tuner [32, 33. The oxygen excess ratio control scheme that will be considered in this subsection is shown in Figure 6. The output of the FSTPID controller is given by

$$
u_{F S T P I D}(t)=k_{p} e(t)+k_{i} \int e(t) d t+k_{d} \frac{d e(t)}{d t} .
$$

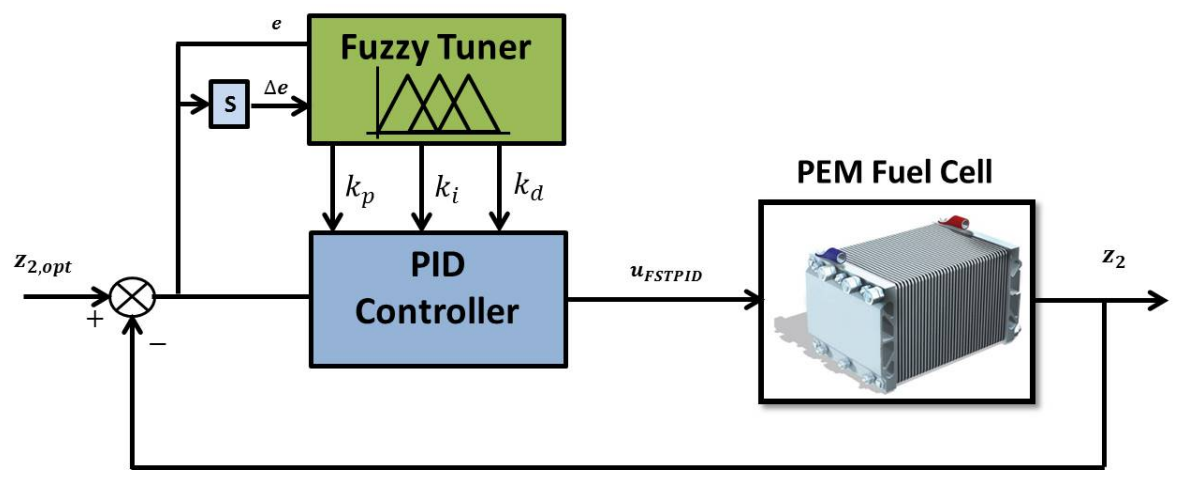

Figure 6: Fuzzy self-tuning PID Controller structure

Further details about the fuzzy tuner are shown in Figure 7. In that figure, there are two inputs to the fuzzy inference: $e$ and $\Delta e$, and three outputs: $k_{p}$, $k_{i}$ and $k_{d}$. In Figure 7, variables $e, \Delta e, E$ and $\Delta E$ indicate error, derivative of error, normalized error and normalized derivative of error, respectively, while the parameters $k_{1}, k_{2}$ and $\alpha, \beta$ and $\gamma$ are input/output scaling factors. 


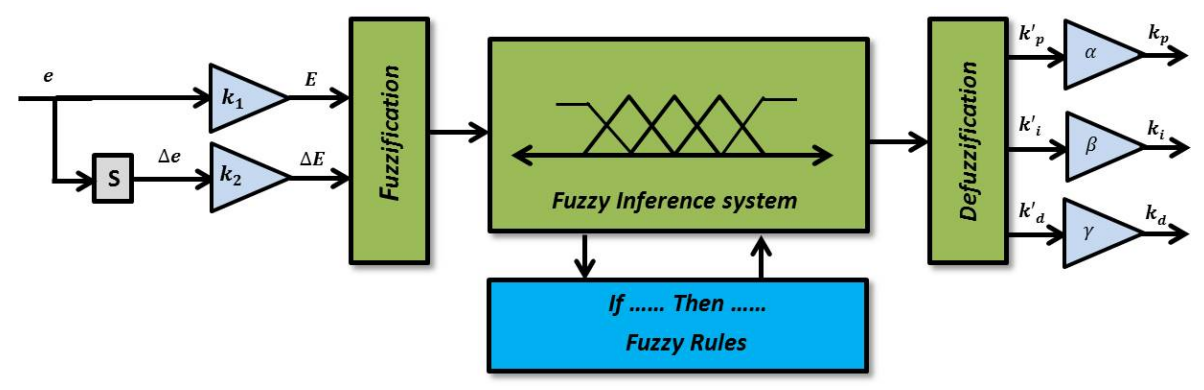

Figure 7: Structure of the fuzzy tuner

In order to determine the domain of each PID parameter, several simulations of the closed-loop system were carried out. Therefore, domains for those parameters were defined as $k_{p} \in[0,1000], k_{i} \in[0,400]$ and $k_{d} \in[0,1]$. Thus, they can be scaled over the fuzzy interval $[0,1]$ as follows:

$$
\begin{aligned}
k_{p}^{\prime} & =\frac{k_{p}-k_{p}^{\min }}{k_{p}^{\max }-k_{p}^{\min }}=\frac{k_{p}}{\alpha}, \\
k_{i}^{\prime} & =\frac{k_{i}-k_{i}^{\min }}{k_{i}^{\max }-k_{i}^{\min }}=\frac{k_{i}}{\beta}, \\
k_{d}^{\prime} & =\frac{k_{d}-k_{d}^{\min }}{k_{d}^{\max }-k_{d}^{\min }}=\frac{k_{d}}{\gamma},
\end{aligned}
$$

with $\alpha=1000, \beta=400$ and $\gamma=1$, while the fuzzy interval for $E$ and $\Delta E$ is $[-1,1]$.

The fuzzy subsets of inputs and outputs are negative, zero and positive. The membership functions of inputs and outputs are respectively depicted in Figures $8(\mathrm{a})$ and 8(b) As shown in Table 2, the columns represent the normalized feedback error $E$ and the rows represent the normalized derivative of error $\Delta E$. Each pair $(E, \Delta E)$ determines the output parameters corresponding to $k_{p}^{\prime}, k_{i}^{\prime}$ and $k_{d}^{\prime}$.

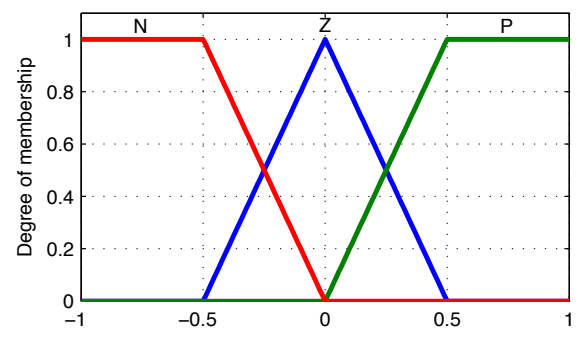

(a) $E$ and $\Delta E$

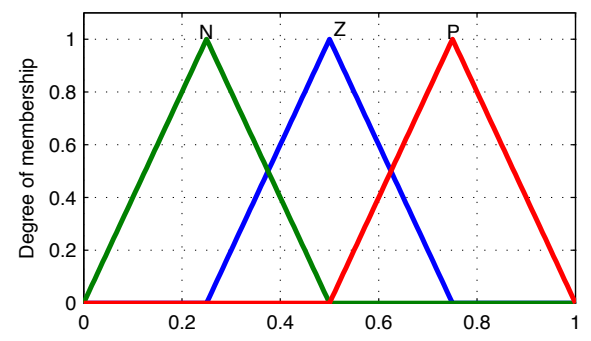

(b) $k_{p}^{\prime}, k_{i}^{\prime}$ and $k_{d}^{\prime}$

Figure 8: Membership functions 
Table 2: Fuzzy rules for FSTPID

\begin{tabular}{|c|l|l|l|l|}
\hline \multirow{2}{*}{$k_{p}^{\prime}, k_{i}^{\prime}, k_{d}^{\prime}$} & \multicolumn{3}{|c|}{$E$} \\
\cline { 3 - 5 } & $\mathbf{N}$ & $\mathbf{Z}$ & $\mathbf{P}$ \\
\hline \multirow{3}{*}{$\Delta E$} & $\mathbf{N}$ & ZNN & ZNN & PNN \\
\cline { 2 - 5 } & $\mathbf{Z}$ & PZZ & ZZN & ZNN \\
\cline { 2 - 5 } & $\mathbf{P}$ & PPP & ZPN & NPN \\
\hline
\end{tabular}

The fuzzy tuner adopted in this paper considers product-sum as the inference method, centre of gravity as the defuzzification method and triangular-shaped as the membership functions for the inputs and outputs. In addition, the relation between the inputs and the outputs of the fuzzy tuner is calculated by [34] as follows:

$$
k_{p}^{\prime}=\frac{\sum_{k=1}^{m} \mu_{k_{p k}^{\prime}}\left(C_{p}\right) C_{p k}}{\sum_{k=1}^{m} \mu_{k_{p k}^{\prime}}\left(C_{p}\right)},
$$

where $C_{p k}$ is the central value of fuzzy set at the $k-t h$ rule and $\mu_{k_{p k}^{\prime}}$ is the output membership value. The same result can be calculated for both $k_{i}^{\prime}$ and $k_{d}^{\prime}$.

\subsection{Hybrid Fuzzy-PID Controller}

A hybrid fuzzy-PID controller (HFPID) is developed to enhance the dynamic and steady-state performance of the oxygen excess ratio regulation. This controller derives its strength from the advantages of both fuzzy and PID controllers together. In addition, the gain adjustment of PID with a fuzzy tuner is included to ameliorate the controller. The control scheme in Figure 9 consists of three parts: a fuzzy-based self-tuned PID controller, a fuzzy controller and a fuzzy selector. Based on the fuzzy rules and depending on the error between the current value of oxygen excess ratio and its setpoint value, the fuzzy selector determines, in a suitable way, when and how to switch the controller. If the output value of the system is far away from the setpoint, the fuzzy controller has the largest effect on the control system. Similarly, when the output value is near the setpoint value, the fuzzy-based self-tuned PID controller has, in turn, the largest effect over the system rather than the fuzzy controller. Notice that the fuzzy-based self-tuned PID controller has better accuracy near the setpoint [35. 


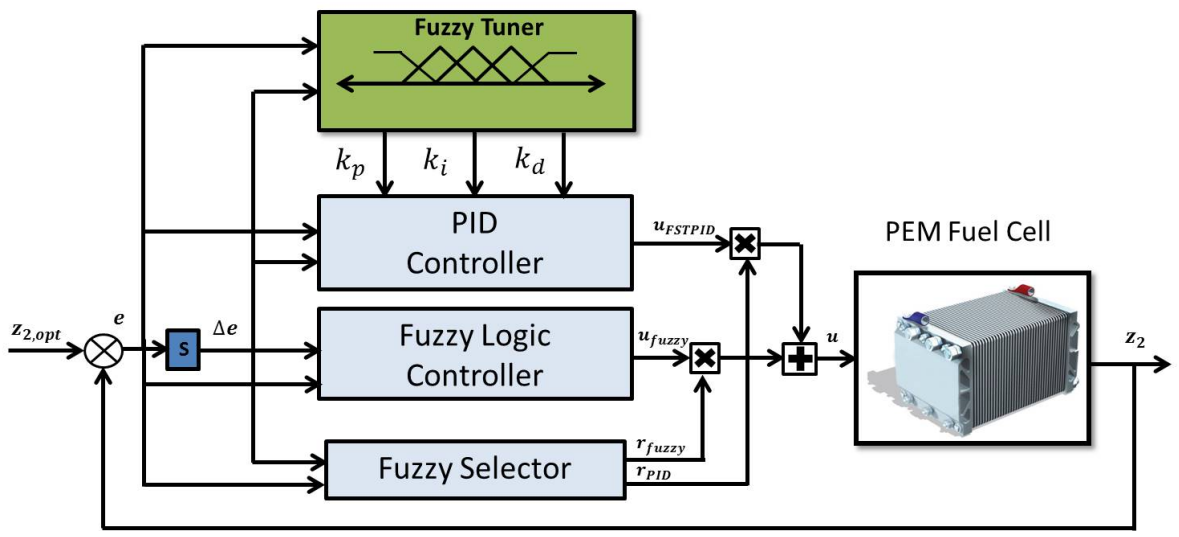

Figure 9: Proposed hybrid fuzzy-PID controller structure

As show in Figure 9, the inputs of the fuzzy selector are $e$ and $\Delta e$, and the fuzzy linguistic variables of input are N, Z and P. The output of the fuzzy selector is the fuzzy control coefficient $r_{f u z z y}$, and the fuzzy linguistic variables related to the output are $\mathrm{P}$ and $\mathrm{PB}$. The fuzzy inference rules are shown in Table 3. The membership functions of inputs and output are shown in Figures 10(a) and 10(b), respectively.

The $r_{P I D}$ and $r_{f u z z y}$ are the adjustment coefficients of both the PID and the fuzzy control law. Moreover, $r_{P I D}+r_{f u z z y}=1$. Hence, the output of the HFPID controller is given by the following expression:

$$
u(t)=r_{P I D} u_{F S T P I D}(t)+r_{f u z z y} u_{f u z z y}(t) .
$$

Table 3: Linear rule base for fuzzy selector

\begin{tabular}{|c|c|c|c|c|}
\hline \multirow{2}{*}{$r_{\text {fuzzy }}$} & \multicolumn{3}{|c|}{$E$} \\
\cline { 3 - 5 } \multicolumn{2}{|c|}{} & $\mathbf{N}$ & $\mathbf{Z}$ & $\mathbf{P}$ \\
\hline \multirow{3}{*}{$\Delta E$} & $\mathbf{N}$ & $\mathrm{P}$ & $\mathrm{P}$ & $\mathrm{P}$ \\
\cline { 2 - 5 } & $\mathbf{Z}$ & $\mathrm{PB}$ & $\mathrm{P}$ & $\mathrm{PB}$ \\
\cline { 2 - 5 } & $\mathbf{P}$ & $\mathrm{P}$ & $\mathrm{P}$ & $\mathrm{P}$ \\
\hline
\end{tabular}




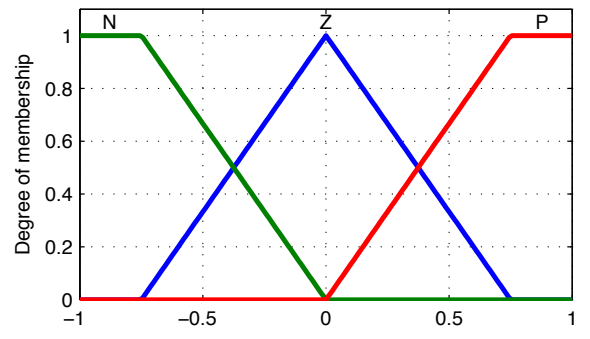

(a) $E$ and $\Delta E$

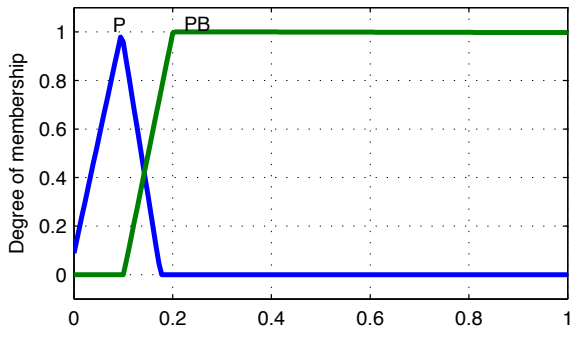

(b) $r_{f u z z y}$

Figure 10: Membership functions of the fuzzy selector

Based on the proposed control structure of Figure 9, the design procedure of the hybrid fuzzy-PID controller can be outlined as follows:

- Step 1: Design the fuzzy logic controller as in Subsection 3.2 .

- Step 2: Design the fuzzy-based self-tuned PID controller as in Subsection 3.3 .

- Step 3: Design the fuzzy selector using $e$ and $\Delta e$.

- Step 4: Calculate the global control $u(t)$ from (10).

Remark 1: Concerning the stability issue, it has been said in [36] that the stability analysis appears something unrelated for fuzzy controllers. They are implicitly supposed robust since they are based on the human experience. And when the PID controller is placed within the loop, the stability feature should be related to the PID controllers. This analysis is deeply discussed in [37.

\section{Simulation Results and Discussion}

To verify the performance, the robustness and the efficiency of the proposed control strategy, detailed simulations are performed and analysed. Simulations are divided into three groups: performance results, sensibility analysis and comparison study. The numerical parameters used in the simulation are given in Table A.2 in Appendix A. The main aim of the design of these controllers is to regulate the oxygen excess ratio at a setpoint value, which is assumed equal to 2.05. With this setpoint, it can be assured that the PEMFC system works within the range of its maximum net power for each load variation while the oxygen starvation is avoided.

\subsection{Performance Results}

This subsection shows a comparison study between the control strategies presented in this paper, i.e., PID, fuzzy logic, fuzzy-based self-tuned PID and the hybrid fuzzy-PID. The dynamic behaviour of $z_{2}$ under different stack current variation (see Figure 11), using PID, FLC, FSTPID and HFPID control 
strategies is shown in Figure 12. The stack current rises up from $150 \mathrm{~A}$ to $200 \mathrm{~A}$ at $t=5 \mathrm{~s}$. Next, after $5 \mathrm{~s}$, it increases by $50 \mathrm{~A}$. This increment stopped when the stack current reaches $300 \mathrm{~A}$. After $20 \mathrm{~s}$, the current falls to $250 \mathrm{~A}$. Finally, at time $t=25 \mathrm{~s}$, it increases again from $250 \mathrm{~A}$ to $300 \mathrm{~A}$ (Figure 11). It can be seen from Figure 12 that all the applied control strategies adjust $z_{2}$ at the setpoint with a satisfactory tracking performance.

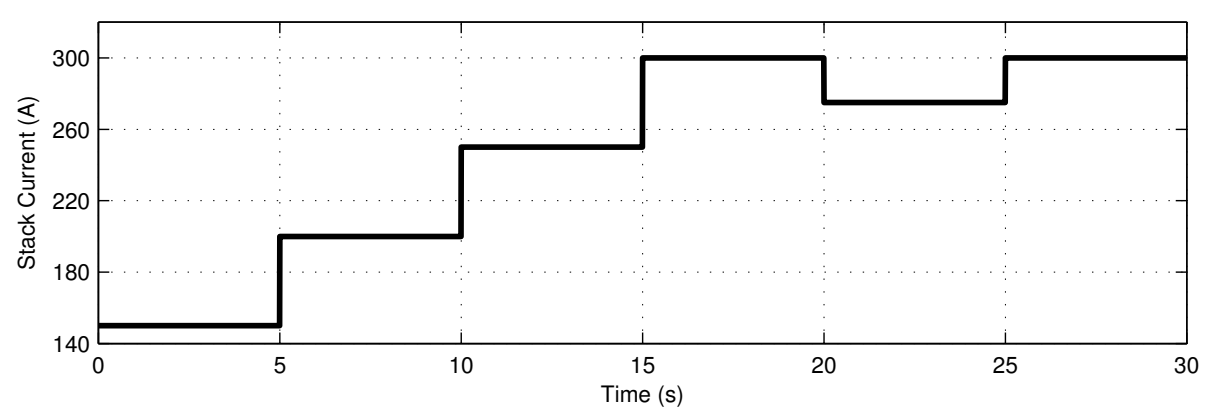

Figure 11: Stack current variation

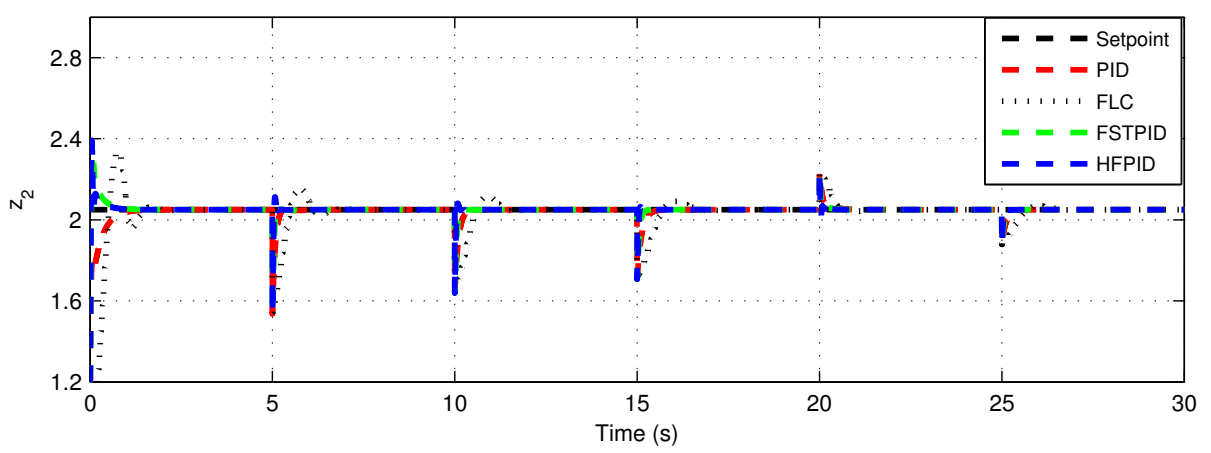

Figure 12: Response of oxygen excess ratio for different control strategies 


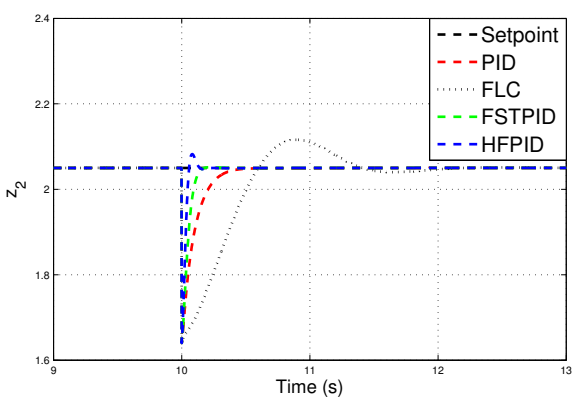

(a) Variation at $t=10 \mathrm{~s}$

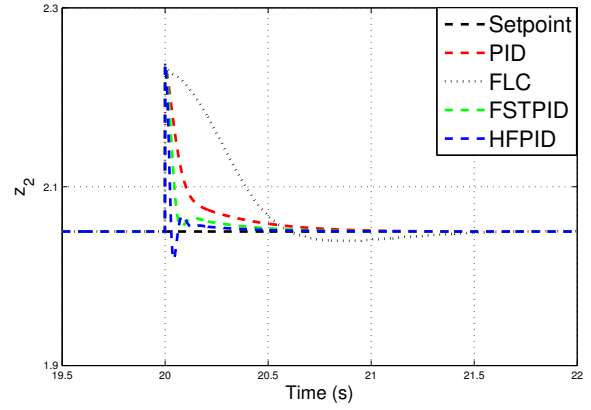

(b) Variation at $t=20 \mathrm{~s}$

Figure 13: The zoomed plot of oxygen excess ratio variations

Figures $13(\mathrm{a})$ and $13(\mathrm{~b})$ present the zoomed plot of $z_{2}$ when the stack current is increased from $200 \mathrm{~A}$ to $250 \mathrm{~A}$ (at $t=10 \mathrm{~s}$ ) and when the stack current is decreased from $300 \mathrm{~A}$ to $250 \mathrm{~A}$ (at $t=20 \mathrm{~s}$ ), respectively. In the former case, the oxygen excess ratio decreases, as shown in Figure 13(a) due to the depletion of the oxygen at the cathode side. This fact caused an important drop of the stack voltage, as shown in Figure 14. An inverse case is shown in Figure 13(b) at $t=20 \mathrm{~s}$. According to the zoomed plot of $z_{2}$ (Figures $13(\mathrm{a})$ and $13(\mathrm{~b})$, it is found that the HFPID controller exhibits a faster time response compared to the other control strategies. As it can be seen in Figure 12 and Table 4 , that the HFPID controller reduces the rise time and the settling time of tuning $z_{2}$ during the transient step changes of $w$ with respect to the FL and FSTPID controllers. The results in Table 4 show also, in terms of several performance indices including: the Integral Squared Error (ISE), the Integral Absolute Error (IAE) and the Integral Time-weighted Absolute Error (ITAE), that the proposed control strategy performs much better than the FL and FSTPID control strategies.

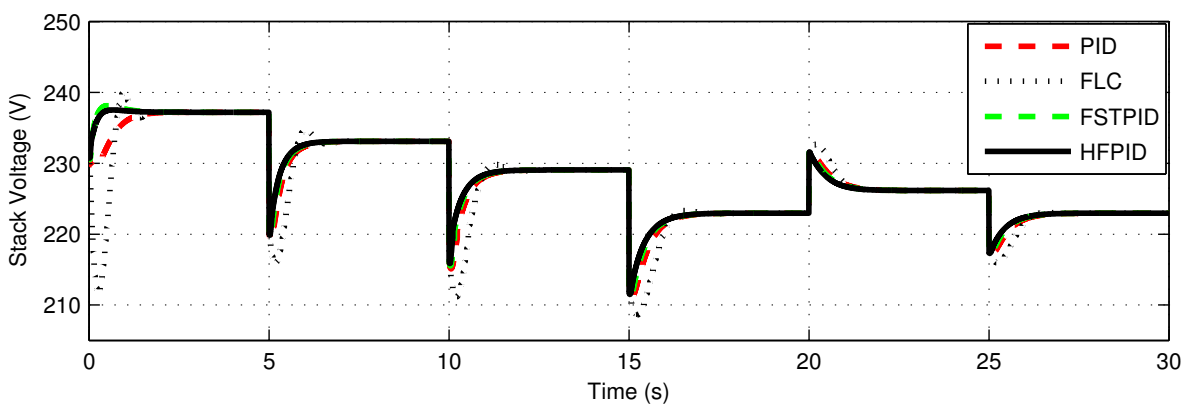

Figure 14: Stack voltage variation for different control strategies 
Table 4: Performance index comparison and time-domain specifications

\begin{tabular}{|c|c|c|c|c|c|c|}
\hline Controllers & ISE & IAE & ITAE & $\begin{array}{c}\text { Overshoot } \\
\mathbf{( \% )}\end{array}$ & $\begin{array}{c}\text { Rise } \\
\text { Time } \\
(\mathbf{s})\end{array}$ & $\begin{array}{c}\text { Settling } \\
\text { Time } \\
\mathbf{( 5 \% )}(\mathbf{s})\end{array}$ \\
\hline PID & 0.0627 & 0.2903 & 2.2741 & 9.037 & 0.55 & 0.14 \\
\hline FLC & 0.5045 & 1.1047 & 8.0201 & 13.95 & 0.6 & 0.43 \\
\hline FSTPID & 0.036 & 0.1577 & 1.1548 & 13.65 & 0.17 & 0.07 \\
\hline HFPID & 0.0249 & 0.1005 & 0.6781 & 15.1 & 0.06 & 0.04 \\
\hline
\end{tabular}

To further show the effectiveness of the proposed control strategy (HFPID) on the PEMFC systems, changes of $z_{2, \text { opt }}$ are considered, rising up from 2.05 to 3 at $t=12 \mathrm{~s}$ and then, falling to 2.05 at $t=22 \mathrm{~s}$. Simulation results show in Figure 15 that $z_{2}$ suitably and accurately tracks $z_{2, \text { opt }}$ in the presence of $I_{s t}$ variation.

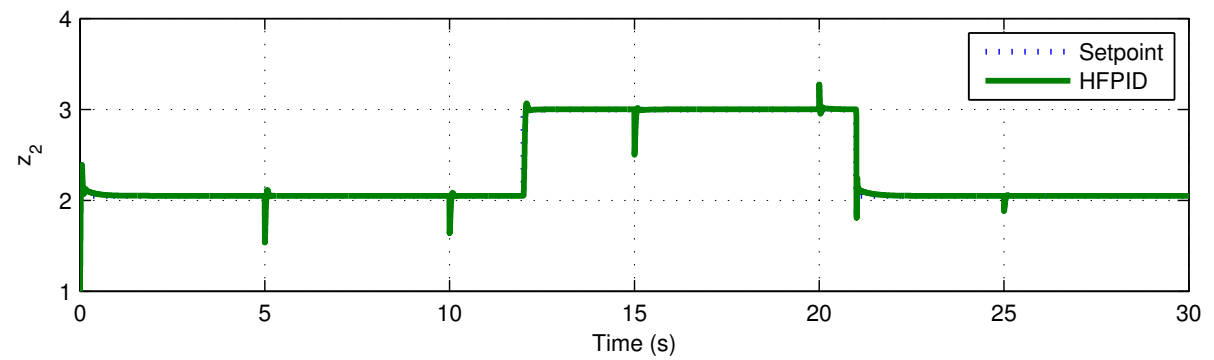

Figure 15: Regulation of oxygen excess ratio with changing reference

The behavior of the compressor motor input voltage $(u)$ is depicted in Figure 16(a). Figures 16(b) and 16(c) exhibit the control action of the fuzzy logic controller $u_{f u z z y}$ and the control action of the fuzzy-based self-tuned PID Controller $u_{F S T P I D}$, respectively. Figure 17 shows the adjustment of the coefficients $r_{f u z z y}$ and $r_{P I D}$. This figure shows that the $r_{f u z z y}$ increases when the current value of $z_{2}$ is so far away from $z_{2, o p t}$, and decreases when that value is near $z_{2, \text { opt }}$. Similarly, the value of $r_{P I D}$ in the steady-state response, which is equal to 0.92 , is greater than the value of $r_{f u z z y}$, which is equal to 0.1 .

\subsection{Sensibility Analysis}

In order to test the robustness of the HFPID controller in the presence of uncertainty, a small variation can be applied to the combined inertia of the compressor and the motor $\left(J_{c p}\right)$, which is related to the capacity of the air to be supplied from the compressor. This uncertainty appears at the time interval $t=[10,20] s$, as shown in Figure 18(b). It can be seen from Figure 18(a) that the HFPID controller exhibits a proper effect over this uncertainty. The zoomed plot is shown in Figure 18(c), where the transient response of $z_{2}$ can be seen at $t=15 \mathrm{~s}$. 


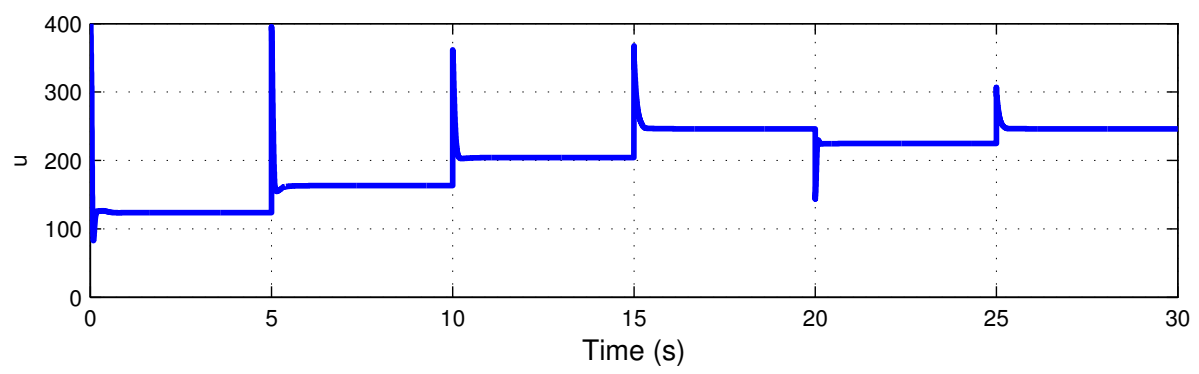

(a) Compressor motor voltage

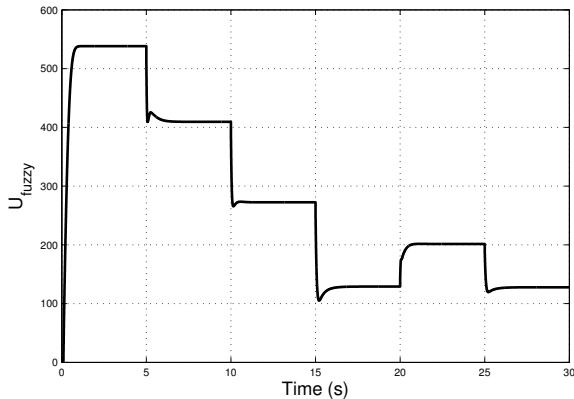

(b) Fuzzy-logic control

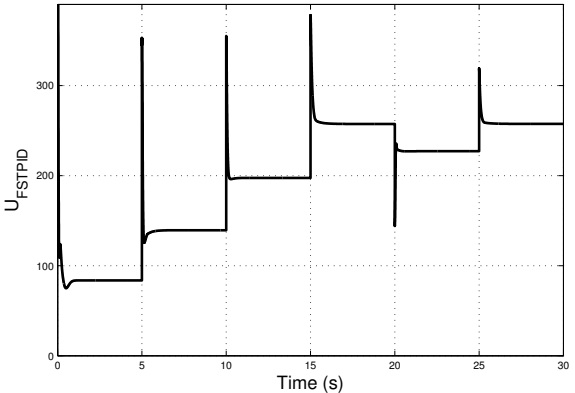

(c) PID control

Figure 16: Control signal components

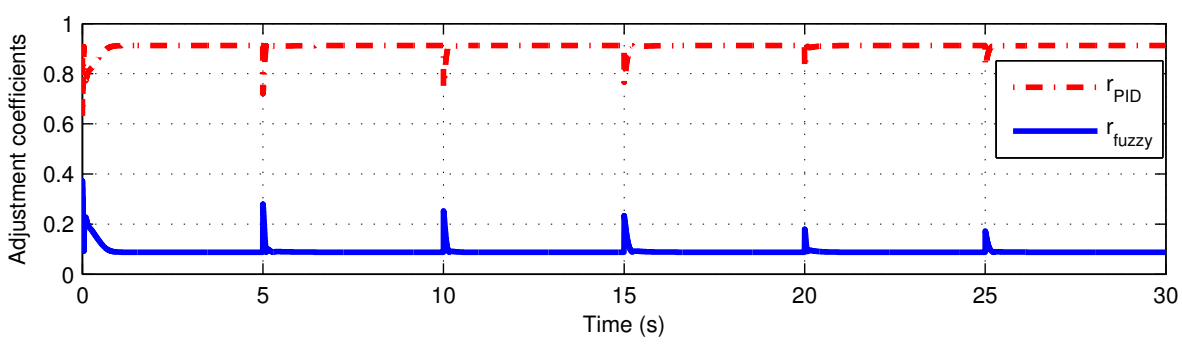

Figure 17: Adjustment coefficients for the fuzzy-logic approach

\subsection{Comparison Results}

In this subsection, it is compared the performance of the controller proposed in this study with one of the new controllers published in the literature for the same control objective. The work in 34 adopted an adaptive PID controller to regulate $z_{2}$ around a reference value $z_{2, r}$, which is taken equal to 2.4 . The parameters of the PID controller are tuned by using an on-line fuzzy logic optimization loop. Simulation are performed taking into account the same $I_{s t}$ profile adopted in 34, which is shown in Figure 19(b), Figure 19(a) exhibits the dynamic behavior of $z_{2}$, which has a proper transient response despite of the 


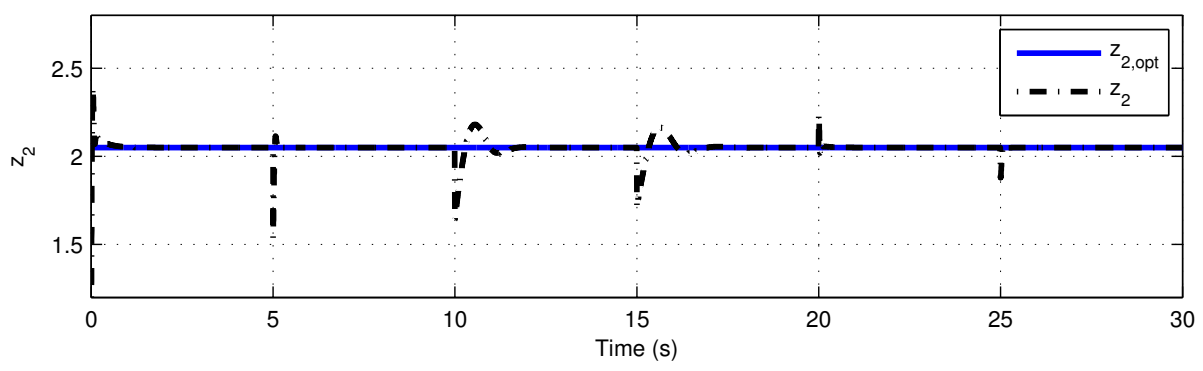

(a) $z_{2}$ considering compressor motor inertia variation

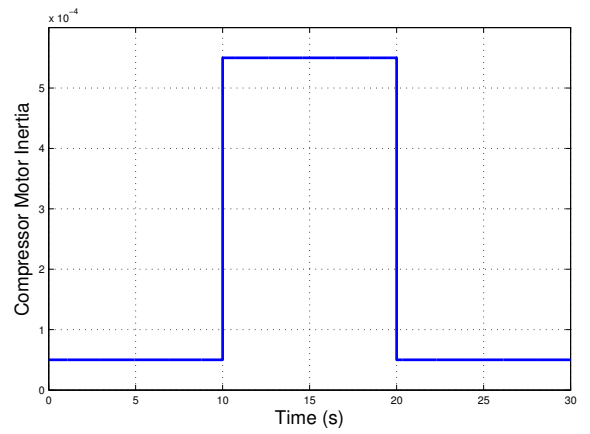

(b) Compressor motor inertia variation

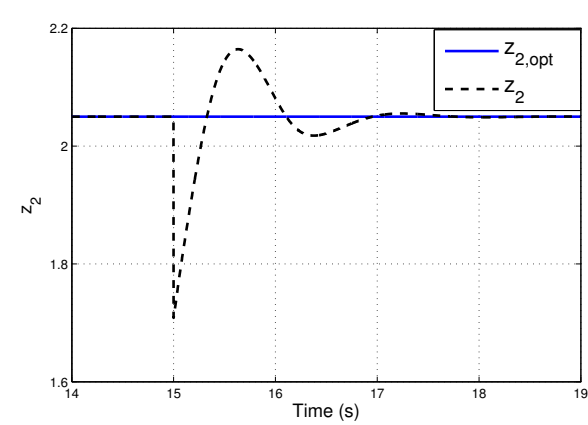

(c) Zoomed plot of $z_{2}$ at $t=15 \mathrm{~s}$

Figure 18: Sensibility analysis

existence of large load variations. Figure 19(c) shows the zoomed plot of $z_{2}$ at $t=15 \mathrm{~s}$, where the proposed control strategy has improved greatly the transient response of $z_{2}$ compared to the control strategy presented in [34. The rising time of $z_{2}$ for the controller adopted in 34 is approximately $150 \mathrm{~ms}$ reduced to $60 \mathrm{~ms}$ in the control scheme proposed in this paper (see Figure 19(c)).

\section{Conclusions}

In this paper, a reduced PEMFC system model is proposed, which presents cathode mass flow transients. Based on this model, a novel hybrid fuzzy-PID controller is designed to regulate the oxygen excess ratio during fast current transitions. The proposed strategy is separated into three parts: fuzzy control, fuzzy-based self-tuned PID control and fuzzy selector. The latter is used to switch the control model between fuzzy-based self-tuned PID and fuzzy logic controllers. Simulation results show that the novel hybrid fuzzy-PID controller performed significantly better than the other control strategies. This is due to the automatic readjustments of the PID parameters done by the fuzzy tuner although the variation of parameters of the PEMFC system and the combination of both advantages of PID controller and FLC. As future research, the 


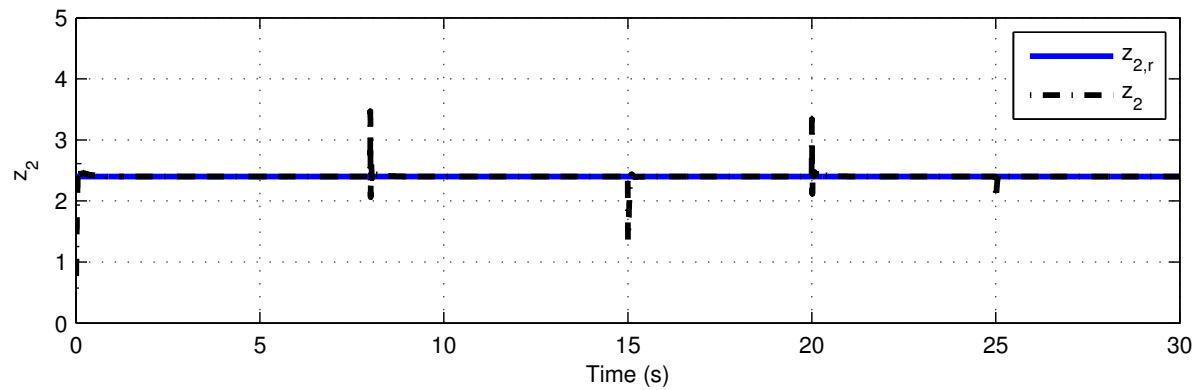

(a) $z_{2}$ variation using HFPID

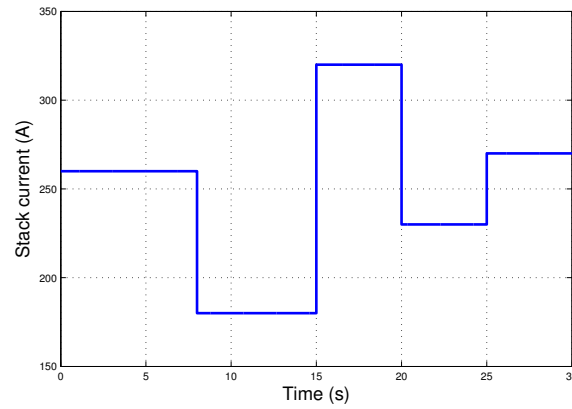

(b) $I_{s t}$ variation

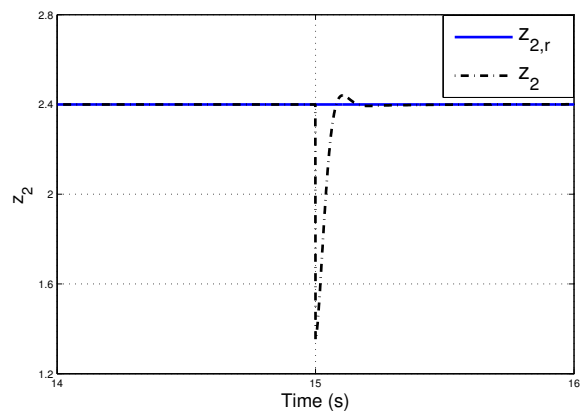

(c) Zoomed plot of $z_{2}$ variation at $t=15 \mathrm{~s}$

Figure 19: Comparison results

applicability of the HFPID controller will be confirmed in a sensorless control scheme.

\section{Acknowledgement}

This work was supported by Laboratoire d'Analyse et de Commande des Systmes d'Énergies et Réseaux Électriques. Université Amar Telidji de Laghouat, Laghouat 03000, Algérie.

\section{References}

[1] N. Yousfi-Steiner, P. Mootguy, D. Candusso, D. Hissel, A review on polymer electrolyte membrane fuel cell catalyst degradation and starvation issues: Causes, consequences and diagnostic for mitigation, Journal of Power Sources 194 (1) (2009) $130-145$.

[2] N. Mebarki, T. Rekioua, Z. Mokrani, D. Rekioua, S. Bacha, PEM fuel cell/ battery storage system supplying electric vehicle, International Journal of Hydrogen Energy 41 (45) (2016) 20993 - 21005. doi:http://dx.doi.org/ $10.1016 / j . i j h y d e n e .2016 .05 .208$ 
[3] S. Peighambardoust, S. Rowshanzamir, M. Amjadi, Review of the proton exchange membranes for fuel cell applications, International Journal of Hydrogen Energy 35 (17) (2010) 9349 - 9384.

[4] S. Cheng, C. Fang, L. Xu, J. Li, M. Ouyang, Model-based temperature regulation of a PEM fuel cell system on a city bus, International Journal of Hydrogen Energy 40 (39) (2015) 13566 - 13575. doi:http://dx.doi. org/10.1016/j.ijhydene.2015.08.042.

[5] E. zgirgin, Y. Devrim, A. Albostan, Modeling and simulation of a hybrid photovoltaic (pv) module-electrolyzer-PEM fuel cell system for micro-cogeneration applications, International Journal of Hydrogen Energy 40 (44) (2015) 15336 - 15342. doi:http://dx.doi.org/10.1016/ j.ijhydene.2015.06.122.

[6] Z. Liu, H. Zhang, C. Wang, Z. Mao, Numerical simulation for RIB and channel position effect on PEMFC performances, International Journal of Hydrogen Energy 35 (7) (2010) 2802 - 2806.

[7] J. Larminie, A. Dicks, M. S. McDonald, Fuel cell systems explained, Vol. 2, Wiley New York, 2003.

[8] Z. Liu, Z. Mao, C. Wang, W. Zhuge, Y. Zhang, Numerical simulation of a mini PEMFC stack, Journal of Power Sources 160 (2) (2006) 1111 - 1121.

[9] J. Pukrushpan, A. Stefanopoulou, H. Peng, Control of fuel cell breathing, IEEE Control Systems 24 (2) (2004) 30-46.

[10] A. Niknezhadi, M. Allué-Fantova, C. Kunusch, C. Ocampo-Martinez, Design and implementation of LQR/LQG strategies for oxygen stoichiometry control in PEM fuel cells based systems, Journal of Power Sources 196 (9) (2011) $4277-4282$.

[11] C. Kunusch, P. Puleston, M. Mayosky, J. Riera, Sliding mode strategy for PEM fuel cells stacks breathing control using a super-twisting algorithm, IEEE Transactions on Control Systems Technology 17 (1) (2009) 167-174.

[12] Z. Baroud, M. Benmiloud, A. Benalia, Sliding mode controller for breathing subsystem on a PEM fuel cell system, in: 3rd International Conference on Control and Engineering Information Technology (CEIT), 2015, pp. 1-6.

[13] I. Matraji, F. S. Ahmed, S. Laghrouche, M. Wack, Comparison of robust and adaptive second order sliding mode control in PEMFC air-feed systems, International Journal of Hydrogen Energy 40 (30) (2015) 9491 - 9504.

[14] X. Hao, H. Zhang, A. An, X. Liu, L. Chen, Fuzzy double model control for air supply on a PEM fuel cell system, Springer Berlin Heidelberg 355 (2013) 392-400. 
[15] H. Beirami, A. Shabestari, M. Zerafat, Optimal PID plus fuzzy controller design for a PEM fuel cell air feed system using the self-adaptive differential evolution algorithm, International Journal of Hydrogen Energy 40 (30) (2015) $9422-9434$.

[16] Z. Baroud, A. Benalia, C. Ocampo-Martinez, Air flow regulation in fuel cells: An efficient design of hybrid fuzzy-PID contro, Electrotehnica, Electronica, Automatica (EEA) 64 (4) (2016) $28-32$.

[17] F. Bianchi, C. Kunusch, C. Ocampo-Martinez, R. Sánchez-Peña, A gainscheduled LPV control for oxygen stoichiometry regulation in PEM fuel cell systems, IEEE Transactions on Control Systems Technology 22 (5) (2014) $1837-1844$.

[18] F. Bianchi, C. Ocampo-Martinez, C. Kunusch, R. Sánchez-Peña, Faulttolerant unfalsified control for PEM fuel cell systems, IEEE Transactions on Energy Conversion 30 (1) (2015) 307-315.

[19] C. Ziogou, S. Papadopoulou, M. Georgiadis, S. Voutetakis, On-line nonlinear model predictive control of a PEM fuel cell system, Journal of Process Control 23 (4) (2013) $483-492$.

[20] Q. Chen, L. Gao, R. Dougal, S. Quan, Multiple model predictive control for a hybrid proton exchange membrane fuel cell system, Journal of Power Sources 191 (2) (2009) $473-482$.

[21] Y. Chang, S. Moura, Air flow control in fuel cell systems: An extremum seeking approach, in: American Control Conference, 2009, pp. 1052-1059.

[22] P. Almeida, M. Simoes, Neural optimal control of PEM fuel cells with parametric CMAC networks, IEEE Transactions on Industry Applications 41 (1) (2005) 237-245.

[23] L. Zadeh, Fuzzy sets, Information and Control 8 (3) (1965) 338 - 353.

[24] E. Mamdani, Application of fuzzy algorithms for control of simple dynamic plant, Proceedings of the Institute of Electrical Engineers 121 (1974) 15851588(3).

[25] K. W. Suh, Modeling, analysis and control of fuel cell hybrid power systems, Ph.D. thesis (2006).

[26] J. Pukrushpan, A. Stefanopoulou, H. Peng, Fuel Cell System Model: Fuel Cell Stack, in: Control of Fuel Cell Power Systems, Springer London, 2004.

[27] J. Gruber, C. Bordons, F. Dorado, Nonlinear control of the air feed of a fuel cell, in: American Control Conference, 2008, pp. 1121-1126.

[28] A. O'Dwyer, Handbook of PI and PID controller tuning rules, Vol. 57, World Scientific, 2009. 
[29] K. Sinthipsomboon, I. Hunsacharoonroj, J. Khedari, P. Pratumsuwan, W. Pongaen, A Hybrid of Fuzzy and Fuzzy Self-Tuning PID Controller for Servo Electro-Hydraulic System, INTECH Open Access Publisher, 2012.

[30] A. Fereidouni, M. Masoum, M. Moghbel, A new adaptive configuration of PID type fuzzy logic controller, ISA transactions 56 (2015) 222-240.

[31] S. Bouallègue, F. Toumi, J. Haggège, P. Siarry, Advanced metaheuristicsbased approach for fuzzy control systems tuning, in: Z. Quanmin, A. T. Ahmad (Eds.), Complex System Modelling and Control Through Intelligent Soft Computations, Springer International Publishing, 2015, pp. 627-653.

[32] Z. Baroud, M. Benmiloud, A. Benalia, Fuzzy self-tuning PID controller for air supply on a PEM fuel cell system, in: 4th International Conference on Electrical Engineering (ICEE), 2015, pp. 1-4.

[33] L. Zulfatman, M. Rahmat, Application of self-tuning fuzzy PID controller on industrial hydraulic actuator using system identification approach, International Journal on Smart Sensing and Intelligent Systems 2 (2) (2009) 246-261.

[34] K. Ou, Y. Wang, Z. Li, Y. Shen, D. Xuan, Feedforward fuzzy-PID control for air flow regulation of PEM fuel cell system, International Journal of Hydrogen Energy 40 (35) (2015) 11686 - 11695.

[35] S. Dequan, G. Guili, G. Zhiwei, X. Peng, Application of expert fuzzy PID method for temperature control of heating furnace, Procedia Engineering 29 (2012) $257-261$.

[36] H.-J. Zimmermann, Fuzzy set theory and its applications, Springer Science \& Business Media, 2001.

[37] K. H. Ang, G. Chong, Y. Li, PID control system analysis, design, and technology, IEEE Transactions on Control Systems Technology 13 (4) (2005) $559-576$. 


\section{Appendix A. Equations, Constants and Parameters of the PEMFC system}

The nonlinear dynamic model is described by the following differential equations:

$$
\begin{aligned}
& \frac{d x_{1}(t)}{d t}=c_{1}\left(x_{4}(t)-\chi(t)\right)-\frac{c_{3} x_{1}(t) \alpha(t)}{c_{4} x_{1}(t)+c_{5} x_{2}(t)+c_{6}}-c_{7} w(t) \\
& \frac{d x_{2}(t)}{d t}=c_{8}\left(x_{4}(t)-\chi(t)\right)-\frac{c_{3} x_{2}(t) \alpha(t)}{c_{4} x_{1}(t)+c_{5} x_{2}(t)+c_{6}} \\
& \frac{d x_{3}(t)}{d t}=-c_{9} x_{3}(t)-\frac{c_{10}}{x_{3}(t)}\left(\left(\frac{x_{4}(t)}{c_{14}}\right)^{c_{12}}-1\right) h_{y 3}(t)+c_{13} u(t) \\
& \frac{d x_{4}(t)}{d t}=c_{14}\left(1+\left(c_{15}\left(\frac{x_{4}(t)}{c_{11}}\right)^{c_{12}}-1\right)\right)\left(h_{y 3}(t)-c_{16}\left(x_{4}(t)-\chi(t)\right)\right)
\end{aligned}
$$

where

$$
\begin{aligned}
& \chi(t)=x_{1}(t)+x_{2}(t)+c_{2} \\
& \alpha(t)=\left\{\begin{array}{lll}
c_{17} \chi(t)\left(\frac{c_{11}}{\chi(t)}\right)^{c_{18}} \sqrt{1-\left(\frac{c_{11}}{\chi(t)}\right)^{c_{12}}} & \text { if } \frac{c_{11}}{\chi(t)}>c_{19} \\
c_{20} \chi(t) & \text { if } \frac{c_{11}}{\chi(t)} \leq c_{19}
\end{array}\right.
\end{aligned}
$$

and coefficients $c_{i}$, for $i=1, \ldots, 24$, are defined in Table A.1. Moreover,

$$
\begin{aligned}
& z_{1}(t)=h_{y 1}(t) w(t)-c_{21} u(t)\left(u(t)-c_{22} x_{3}(t)\right), \\
& z_{2}(t)=\frac{c_{23}\left(x_{4}(t)-\chi(t)\right)}{c_{24} w(t)} .
\end{aligned}
$$

Table A.1: Constants of the PEMFC system model

\begin{tabular}{|l|l|}
\hline$c_{1}=\frac{R T_{s t} k_{c a, i n}}{M_{O_{2}} V_{c a}}\left(\frac{x_{O_{2}, a t m}}{1+\omega_{a t m}}\right)$ & $c_{15}=\frac{1}{\eta_{c p}}$ \\
$c_{2}=p_{s a t}$ & $c_{16}=k_{c a, i n}$ \\
$c_{3}=\frac{R T_{s t}}{V_{c a}}$ & $c_{17}=\frac{C_{D} A_{T}}{\sqrt{R T_{s t}}} \sqrt{\frac{2 \gamma}{\gamma-1}}$ \\
$c_{4}=M_{O_{2}}$ & $c_{18}=\frac{1}{\gamma}$ \\
$c_{5}=M_{N_{2}}$ & $c_{19}=\left(\frac{2}{\gamma+1}\right)^{\frac{\gamma}{\gamma-1}}$ \\
$c_{6}=M_{v} p_{s a t}$ & \\
$c_{7}=\frac{R T_{s t} n}{4 F V_{c a}}$ & $c_{20}=\frac{C_{D} A_{T}}{\sqrt{R T_{s t}}} \gamma^{0.5}\left(\frac{2}{\gamma+1}\right)^{\frac{\gamma+1}{2 \gamma-2}}$ \\
$c_{8}=\frac{R T_{s t} k_{c a, i n}}{M_{N_{2}} V_{c a}}\left(\frac{1-x_{O_{2}, a t m}}{1+\omega_{a t m}}\right)$ & $c_{21}=\frac{1}{R_{c m}}$ \\
$c_{9}=\frac{\eta_{c m} k_{t} k_{v}}{J_{c p} R_{c m}}$ & $c_{22}=k_{v}$ \\
$c_{10}=\frac{C_{p} T_{a t m}}{J_{c p} \eta_{c p}}$ & $c_{23}=k_{c a, i n}\left(\frac{x_{O_{2}, a t m}}{1+\omega_{a t m}}\right)$ \\
$c_{11}=p_{a t m}$ & $c_{24}=\frac{n M_{O_{2}}}{4 F}$ \\
$c_{12}=\frac{\gamma-1}{\gamma}$ & $x_{O_{2}, a t m}=\frac{y_{O_{2}, a t m} M_{O_{2}}}{M_{a, a t m}}$ \\
$c_{13}=\frac{\eta_{c m} k_{t}}{J_{c p} R_{c m}}$ & $\omega_{a t m}=\frac{M_{v}}{M_{a, a t m}} \frac{\phi_{a t m} p_{s a t}}{p_{a t m}-\phi_{a t m} p_{s a t}}$ \\
$c_{14}=\frac{R_{T_{a t m} \gamma}}{M_{a, a t m} V_{s m}}$ &
\end{tabular}


Table A.2: Simulation Parameters

\begin{tabular}{|c|c|c|c|}
\hline Parameter & Description & Value & Unit \\
\hline$\eta_{c p}$ & Motor mechanical efficiency & 0.98 & $\%$ \\
\hline$\eta_{c m}$ & Compressor efficiency & 0.8 & $\%$ \\
\hline$J_{c p}$ & Compressor inertia & $5 \times 10^{-5}$ & $\mathrm{~kg} \mathrm{~m}^{2}$ \\
\hline$R_{c m}$ & Compressor motor resistance & 0.82 & $\Omega$ \\
\hline$k_{t}$ & Motor parameter & 0.0153 & $(\mathrm{Nm}) / \mathrm{A}$ \\
\hline$k_{v}$ & Motor parameter & 0.0153 & $\mathrm{~V} /(\mathrm{rad} / \mathrm{s})$ \\
\hline$M_{a, a t m}$ & Air molar mass & $29 \times 10^{-3}$ & $\mathrm{~kg} \mathrm{~mol}^{-1}$ \\
\hline$M_{\mathrm{O}_{2}}$ & Oxygen molar mass & $32 \times 10^{-3}$ & $\mathrm{~kg} \mathrm{~mol}^{-1}$ \\
\hline$M_{N_{2}}$ & Nitrogen molar mass & $28 \times 10^{-3}$ & $\mathrm{~kg} \mathrm{~mol}^{-1}$ \\
\hline$M_{v}$ & Vapor molar mass & $18 \times 10^{-3}$ & $\mathrm{~kg} \mathrm{~mol}^{-1}$ \\
\hline$y_{\mathrm{O}_{2}, a t m}$ & Oxygen mole fraction & 0.21 & - \\
\hline$V_{c a}$ & Cathode volume & 0.01 & $\mathrm{~m}^{3}$ \\
\hline$k_{c a, i n}$ & Cathode inlet orifice constant & $0.3629 \times 10^{-5}$ & $\mathrm{~kg} /(\mathrm{sPa})$ \\
\hline$V_{s m}$ & Supply manifold volume & 0.02 & $\mathrm{~m}^{3}$ \\
\hline$T_{s t}$ & Stack temperature & 353.15 & $\mathrm{~K}$ \\
\hline$T_{a t m}$ & Atmospheric temperature & 298.15 & $\mathrm{~K}$ \\
\hline$p_{a t m}$ & Atmospheric pressure & 101325 & $\mathrm{~Pa}$ \\
\hline$p_{\text {sat }}$ & Saturation pressure & 465327.41 & $\mathrm{~Pa}$ \\
\hline$R$ & Universal gas constant & 8.3145 & $\mathrm{~J} /(\mathrm{mol} \mathrm{K})$ \\
\hline$C_{p}$ & Constant pressure Specific heat of air & 1004 & $\mathrm{~J} /(\mathrm{mol} \mathrm{K})$ \\
\hline$C_{D}$ & Cathode outlet throttle discharge coefficient & 0.0124 & - \\
\hline$\gamma$ & Ratio of specific heat of air & 1.4 & - \\
\hline$A_{T}$ & Cathode outlet throttle area & 0.002 & $\mathrm{~m}^{2}$ \\
\hline$\phi_{a t m}$ & Average ambient air relative humidity & 0.5 & - \\
\hline$n$ & Number of cells in fuel-cell stack & 381 & - \\
\hline$F$ & Faraday number & 96485 & $\mathrm{C} \mathrm{mol}^{-1}$ \\
\hline
\end{tabular}

